\title{
PERCEPTION AND IMPORTANCE OF MENTOR-MENTEE PROGRAMME IN INDIAN INSTITUTE OF TECHNOLOGY (IIT, JODHPUR) TO FIRST YEAR ENGINEERING STUDENT
}

\author{
Siddhant Attri ${ }^{* 1}$ \\ ${ }^{* 1}$ B. Tech (Computer Science) 4th Semester, Indian Institute of Technology (IIT) Jodhpur, \\ Rajasthan, India
}

DOI: https://doi.org/10.29121/IJOEST.v4.i1.2020.67

\begin{abstract}
Background: Mentoring is a crucial step for career success and there is lot of stress of different engineering courses in the new environment along with emotional immaturity and new challenges. A well-designed and structured mentoring programme for the budding engineers has been introduced at IIT. A specialized institutional support is required for an IIT student to facilitate success. To facilitate this high level of success for every student, the approach should be active and antecedent. Mentoring has always been an important part in an engineering students' career.

Material and methods: A mentorship programme were designed for engineering students (n-120) at the Indian Institute of Technology, Jodhpur. Two-day workshop was conducted to sensitize senior students of third semester (n-15) who volunteered to be dedicated mentors. After sensitization, 120 B.Tech first semester students were divided among these mentors by a lottery system. At the end of the mentorship programme, perception of mentors and mentees was done by content analysis of all the data collected by open ended and close ended questionnaire.

Results: A total of 120 students and 15 mentors completed the feedback questionnaire. Mentors themselves consider this programme helpful in their self-improvement as role models, advisors or career counselors and in improving their communication skills and mentees were of the view that the programme helped them emotionally and academically.

Conclusion: Mentor-mentee programme in IIT enhanced the engineering students professional and personal development and both mentors and mentees were extremely satisfied with this programme for career development.
\end{abstract}

Keywords: Mentor; Mentee; Engineering Students; Undergraduates.

\section{INTRODUCTION}

Upon entering the prestigious engineering colleges/ IIT's it is difficult for a student to adjust to new people and new environment initially and some may need psychological support, guidance and counselling. Most of them coming from cozy environment at home and at schools are pampered to glory by the schools. Engineering students secure admission in these prestigious institutes after working hard and most of these students travelled long distance from their home to receive engineering studies and some need psychological support, guidance, counseling- both professional and social. 
A Mentor help the mentee as a guide, teacher, friend and supporter in the development of his career as well as personal and psychological aspects. Mentor with his experience provides support to face the new environment to a new entrant who is under lot of stress and is worried.

Mentoring has a beneficial role both for mentor and mentee to maintain good relationship amongst themselves in the long run. So, relationship has to maintained in a meaningful manner so that both can contribute and get benefit out of it effectively.

An engineering student or any other professional student face so many psychological and emotional problems towards achieving high stakes in academics and career development. For that, good interpersonal relationships are required so that they may not land up in depression. [1]

Term mentoring describes a range of faculty- student, staff- student or student- student relationships. [2,3,4] Mentoring improves students transition to higher institutes and has a positive outcome such as:

- Sense of belonging [5]

- Capacity for socially responsible leadership [6]

- Deep and strategic learning approaches [7] and

- Self-confidence in professional skills and abilities [8]

There is further evidence that mentors may benefit from relationship with undergraduate students, including improved confidence and socio-emotional growth, teaching and communication skills. [9] Mentoring builds relationships with students, locate spaces where they get disconnected and help them reconnect when needed. [10]

There are several ways that a mentor can help to connect with the mentee, but mentee must take the responsibility of outcome of mentor-mentee relationship by building trust and confidence amongst themselves and mentee should ask thoughtful questions without hesitation and fear. As most of these early professionals are shy and reluctant to ask questions with the fear in their mind that they are troubling mentors.

Role of mentee is equally important that he or she should be receptive, responsible, honest, open minded and should not hesitate to share his queries or problems. His proactive role in shaping the relationship is important and he should give proper feedback and should appreciate the mentoring effort. [11]

\section{MATERIAL AND METHODS}

Mentor-mentee programme was designed to ensure that students receiving it should be a quality product as engineers both academically and psychologically. First semester students of engineering were offered a mentor, for psychological support as a counselor as a friend \& guide for development of career in right direction:

B-tech $(n=120)$ students of the first semester as mentees and dedicated mentors were selected from students of $3^{\text {rd }}$ semester of B-tech after thorough interview by the faculty. Selected mentors $(n=15)$ were sensitized by organizing one day workshop on mentorship program. After proper 
consideration mentor-mentee programme was chart out by faculty member (n-5) from different departments volunteered to be part of this programme. One hundred and twenty students of $1^{\text {st }}$ semester was divided among 15 mentors by lottery system. Each mentor has to take care of 8 mentees. Mentor-mentee meetings were compulsory every day $1^{\text {st }}$ week then biweekly $2^{\text {nd }}$ week and for next two months every month. In between if mentee has any query, he could contact mentor without hesitation at any time.

Even the parents of mentees were provided contact numbers of mentors to contact, if their child has any psychological problems. A feedback questionnaire of both mentor and mentees was constructed by reviewing the literature with more stress on mentor-mentee programme. There were closed ended questionnaire both for mentees and mentors, which were validated by dedicated faculty or members of MEU. After 6 months of mentor-mentee programme, the questionnairebased feedback was collected from mentors and mentees and statistical analysis was done using SPSS software version 17.0. The outcome of programme was assessed by validated semistructured questionnaire which were collected from mentors and mentees.

\section{RESULTS}

Mentor-mentee programme introduced for $1^{\text {st }}$ semester B-tech students. All 120 students of either sex participated in this programme and undertook feedback questionnaire. 15 mentors completed the feedback questionnaire. Results were analyzed according to [table- 1-4].

Table 1: Mean response of closed- ended question given by mentees

\begin{tabular}{|l|c|c|}
\hline Questions & Mean+/-SD & Median \\
\hline Did your mentor easily available and accessible? & $4.84+/-0.94$ & 5.00 \\
\hline Did your mentor communicate regularly? & $3.70+/-1.04$ & 4.00 \\
\hline Did your mentor give you emotional and psychological support? & $4.28+/-0.70$ & 4.00 \\
\hline Did your mentor encourage and motivate you? & $4.26+/-0.88$ & 4.00 \\
\hline Did the mentor suggest any other way out to the issues? & $4.12+/-0.87$ & 4.00 \\
\hline $\begin{array}{l}\text { Was your knowledge about course subjects enhanced with mentor's } \\
\text { help? }\end{array}$ & $4.28+/-0.71$ & 4.00 \\
\hline Did your mentor motivate for peer mentoring? & $4.12+/-0.76$ & 4.00 \\
\hline $\begin{array}{l}\text { Was your mentor an ideal role model according to you and would you } \\
\text { keep in touch with him for future personal \& professional activities? }\end{array}$ & $4.90+/-1.03$ & 4.00 \\
\hline $\begin{array}{l}\text { Did you feel that this process of mentor-mentee programe was } \\
\text { rewarding and increase your self-confidence? }\end{array}$ & $3.16+/-1.31$ & 4.00 \\
\hline $\begin{array}{l}\text { Were you satisfied with your mentor's interest and attitude towards } \\
\text { mentoring programme? }\end{array}$ & $4.22+/-1.08$ & 4.00 \\
\hline Was the time period for mentoring programme was sufficient? & $4.32+/-1.00$ & 4.00 \\
\hline Did mentor-mentee programme needed for welfare of students? & $4.42+/-0.62$ & 5.00 \\
\hline
\end{tabular}

*Likert scale used was: Strongly agree: 5, Agree:4, Neither yes nor no: 3, Disagree:2, Strongly disagree:1; SD: standard deviation 
Table 2: perception of mentees on mentorship program- closed-ended questions $(n=112)$

\begin{tabular}{|c|c|c|c|c|c|}
\hline Questions & $\begin{array}{l}\text { Strongly } \\
\text { agree } \\
(\%)\end{array}$ & $\begin{array}{c}\text { Agree } \\
(\%)\end{array}$ & $\begin{array}{c}\text { Neither agree } \\
\text { nor disagree } \\
(\%)\end{array}$ & $\begin{array}{l}\text { Disagree } \\
(\%)\end{array}$ & $\begin{array}{l}\text { Strongly } \\
\text { disagree } \\
(\%)\end{array}$ \\
\hline $\begin{array}{l}\text { Did your mentor easily } \\
\text { available and accessible? }\end{array}$ & 52.56 & 34.83 & 4.50 & 8.11 & 0 \\
\hline $\begin{array}{l}\text { Did your mentor communicate } \\
\text { regularly? }\end{array}$ & 23.41 & 46.24 & 11.6 & 17.86 & 0.89 \\
\hline $\begin{array}{l}\text { Did your mentor give you } \\
\text { emotional and psychological } \\
\text { support? }\end{array}$ & 48.10 & 41.09 & 7.02 & 3.79 & 0 \\
\hline $\begin{array}{l}\text { Did your mentor encourage and } \\
\text { motivate you? }\end{array}$ & 45.42 & 44.76 & 8.03 & 0.89 & 0.90 \\
\hline $\begin{array}{l}\text { Did the mentor suggest any } \\
\text { other way out to the issues? }\end{array}$ & 30.20 & 45.64 & 18.80 & 5.36 & 0 \\
\hline $\begin{array}{l}\text { Was your knowledge about } \\
\text { course subjects enhanced with } \\
\text { mentor's help? }\end{array}$ & 38.57 & 49.00 & 9.03 & 2.60 & 0.80 \\
\hline $\begin{array}{l}\text { Did your mentor motivate for } \\
\text { peer mentoring? }\end{array}$ & 30.14 & 51.89 & 15.20 & 2.77 & 0 \\
\hline $\begin{array}{l}\text { Was your mentor an ideal role } \\
\text { model according to you and } \\
\text { would you keep in touch with } \\
\text { him for future personal \& } \\
\text { professional activities? }\end{array}$ & 44.41 & 28.69 & 17.08 & 8.02 & 1.80 \\
\hline $\begin{array}{l}\text { Did you feel that this process of } \\
\text { mentor-mentee programe was } \\
\text { rewarding and increase your } \\
\text { self-confidence? }\end{array}$ & 19.75 & 36.5 & 24.89 & 17.90 & 0.96 \\
\hline $\begin{array}{l}\text { Was the mentor's attitude } \\
\text { satisfactory? }\end{array}$ & 40.58 & 37.40 & 10.42 & 7.08 & $4 . .52$ \\
\hline $\begin{array}{l}\text { Was the mentoring period } \\
\text { appropriate? }\end{array}$ & 40.58 & 35.39 & 10.43 & 9.03 & 4.57 \\
\hline $\begin{array}{l}\text { Did mentor-mentee programme } \\
\text { needed for welfare of students? }\end{array}$ & 56.46 & 37.34 & 5.31 & 0.89 & 0 \\
\hline
\end{tabular}

Table 3: Mean response of closed-ended questions given by mentors

\begin{tabular}{|l|c|c|}
\hline Questions & Mean +/- SD & Median \\
\hline $\begin{array}{l}\text { Did mentor-mentee programme promote your professional } \\
\text { development? }\end{array}$ & $4.86+/-0.42$ & 5.00 \\
\hline Did mentorship facilitate your personal development? & $3.82+/-0.39$ & 4.00 \\
\hline Did mentorship increase your self-confidence? & $4.13+/-0.39$ & 4.00 \\
\hline Did mentee communicate regularly? & $4.43+/-0.49$ & 5.00 \\
\hline Did mentor anticipate extra burden of mentor-mentee programme? & $1.60+/-0.65$ & 1.50 \\
\hline Would you like to volunteer as mentor for future batches? & $4.60+/-0.65$ & 5.00 \\
\hline
\end{tabular}


Table 4: perception of mentors on mentorship program - closed ended questions ( $\mathrm{n}=16)$

\begin{tabular}{|l|c|c|c|c|c|}
\hline Questions & $\begin{array}{c}\text { Strongly } \\
\text { agree (\%) }\end{array}$ & $\begin{array}{c}\text { Agree } \\
(\mathbf{\%})\end{array}$ & $\begin{array}{c}\text { Neither agrees } \\
\text { nor disagree } \\
(\%)\end{array}$ & $\begin{array}{c}\text { Disagree } \\
(\mathbf{\%})\end{array}$ & $\begin{array}{c}\text { Strongly } \\
\text { disagree } \\
(\%)\end{array}$ \\
\hline $\begin{array}{l}\text { Did mentor-mentee } \\
\text { programme promote your } \\
\text { professional development? }\end{array}$ & 82.23 & 17.77 & 0 & 0 & 0 \\
\hline $\begin{array}{l}\text { Did mentorship facilitate } \\
\text { your personal development? }\end{array}$ & 0 & 90.66 & 9.34 & 0 & 0 \\
\hline $\begin{array}{l}\text { Did mentorship increase } \\
\text { your self-confidence? }\end{array}$ & 34.38 & 65.62 & 0 & 0 & 0 \\
\hline $\begin{array}{l}\text { Did mentee communicate } \\
\text { regularly? }\end{array}$ & 81.32 & 18.68 & 0 & 0 & 0 \\
\hline $\begin{array}{l}\text { Did mentor anticipate extra } \\
\text { burden of mentor-mentee } \\
\text { programme? }\end{array}$ & 0 & 0 & 8.32 & 40.68 & 51 \\
\hline $\begin{array}{l}\text { Would you like to volunteer } \\
\text { as mentor for future } \\
\text { batches? }\end{array}$ & 68.54 & 24.10 & 7.36 & 0 & 0 \\
\hline
\end{tabular}

\section{DISCUSSION}

'Mentor' word is derived from Greek mythology "Odyssey" wherein Odysseus when left for the Trojan war, entrusts the education of his son under care of his faithful friend named 'Mentor'. [12]

What is mentoring? Mentoring of students is to share knowledge, skills and experiences of senior students with the junior students on their exposure to new environment and situation. Moreover, Mentors should be well aware of the mentoring process and how to implement it.

Mentoring can also be defined as "a pairing of more skilled or experienced person, with the lesser skilled person to make them more skillful" Mentor is usually a person at least one level higher in the institution or workplace. [13]

The role and expectation of mentor and mentee is to accept the responsibility of his career. As role of mentor should be clear regarding teaching by proper advice and encourage the mentee in a supportive way. Accept and receive feedback positively and should be clear about their goals and objectives. This complex relationship of mentoring should clearly focus on both short and longterm professional development goals.

Difference between a supervisor and a mentor is helping to build the career of mentee and a natural consequence of care is developed in most of mentees for life as they value advice of mentor and friendship amongst them grow and these contacts are maintained lifelong. And their relationship promotes "the development of growth of mentee's skills and knowledge through the mentor's experience." [14] There is also peer monitoring programmes designed especially for underrepresented populations into science and engineering. Whatever may be the profession like 
politics, business, medical or other academics mentoring relationship as an essential step towards achieving the success in concerned field.[15]

People who have achieved high status in their respective fields often give credit to a mentor during professional transition in their life that mentor was crucial to their success in life and their career growth. As a mentor you offer information, knowledge, experiences, wisdom and provide valuable opportunities by facilitating academic career and moreover information shared by mentee must remain confidential. [16]

Trust is very important and critical component of coaching in mentor and mentee programme. Mentee should keep conversations confidential and mentee should have full faith in him, and mentee should feel comfortable in talking and sharing with mentor without hesitation. Only trustworthy senior colleague's concern and guidance can help in career planning for successful practice of profession is each one's dream. This can only be achieved by good mentoring relationship forever rather than a onetime affair [17]. My study regarding introduction and perception of mentor-mentee programme in $1^{\text {st }}$ year has assessed similar outcome and both mentors and mentees were satisfied with mentor-mentee programme

Qualities of a great mentor are that he should be

- Consistent

- Readily available to solve problems of mentee with proper guidance and advice

- Provide valuable and consistent feedback

- Maintain a professional relationship within and outside mentoring relationship

- Resourceful and reliable

- Capable and trustworthy. [18]

Outcomes of mentee should be

- Effective and faster adjustment to institute environment

- Academic performance enhancement

- Acquiring more self-knowledge and self-leadership capabilities

- Involvement more in cultural and social activities

- And smooth transition. [19]

Coaching has to be differentiated from mentoring relationship as coaching is an immediate performance-based focus whereas Mentoring relationship is one to one process which help mentee to learn, improve skills, develop and take a long term and positive view towards career of a person and success and it's an interaction between an older professional, the mentor, and a younger professional, the mentee. [20]

This mentor-mentee programme has yielded many beneficial results. For the mentor, level of trust and friendship established with their mentees, serves as measure of their success. An important advantage to the mentee is that, it gives a chance to explore their strength and weakness in a safe environment. Mentor encourages broader thinking and challenges assumptions of the mentee. [20] 
For achievement of objectives of mentor-mentee programme most important aspect is choosing the right mentor. A good mentor will focus on personal development and will be self-aware and will have committed approach to win trust of mentee. Selection of committed mentors should be carried out by a selection committee, followed by one or two days of voluntary training. Under the training course dedicated counselling, coaching, active listening and facilitation skills can be practiced. Even though mentoring operates at one is to one and confidential level, it is very important to evaluate the process of mentor-mentee programme and design a feedback which can be collected at the end. [20]

Majority of the problems faced by engineering students are related to academic matters, faculty members and their project works. Some other psychological problems are like anxiety, depression, stress and frustration. In addition to these there are difficulties in completing assigned tasks and lack of problem-solving skills. One specific perception common among students is that usually faculty members are not much concerned about students, which could be due to communication barrier between faculty and students. [19]

Intimate emotions are developed between mentor and mentee after personal issues and problems are discussed by mentee in a cordial atmosphere without hesitation. This level of personal contact between mentor and mentee is much closer as compared to that between student and teacher or role model.

Mentoring continues to be widely accepted as an effective mechanism for positively influencing undergraduate students [21], including improving their academic performance.[22] Due to its positive effects like improved academic results, their persistence in university or in specific discipline- such as science, technology, engineering and mathematics (STEM) mentoring is considered an effective way to improve performance of students. [23]

Many of the participant mentees who were students of the mentors in the beginning later became well known colleagues. A great mentor is not the one who only supervises the mentee, but the one who helps in building career of the mentee. This mentor-mentee programme paved the path for peer mentoring in future but also help the newcomers to adjust and adapt the new environment at the earliest.

\section{CONCLUSION}

The right mentor can impact the career of a budding engineer in many ways and for the success of mentor-mentee programme commitment and belief are the most important components to generate valuable results and for that mentor and mentee should be equally involved. Moreover, successful mentoring takes time. Many fresh students are not mentally prepared for the new environment, which is tougher than their comparatively cozy high school experience, thus mentorship plays an important role in this transition. Mentoring imparts the wisdom and experience beyond classroom and lab settings and make mentees more comfortable in new environment.

For a more effective and successful mentor-mentee programme, involvement of senior faculty member can add benefits of additional skills like time management, teamwork and 
communication. But most of the time the drawback is that either the senior faculty member is not available or not interested to participate in such kind of programme.

Therefore, there is a need to lay out a programme that fulfills the needs of the participants. Training should be imparted to all the dedicated participants involved as mentors and afterwards evaluation should be done for improvement of this mentor-mentee programme so that we can give right direction to the budding engineers for their future career.

\section{ACKNOWLEDGEMENTS}

I acknowledge the guidance and help provided by my colleagues and faculty, mentors and mentees who participated in the study enthusiastically.

\section{CONFLICTS OF INTEREST \& FINANCIAL SUPPORT}

Nil.

\section{REFERENCES}

[1] Han SS, Lee SY, Choi WS, Kim SJ, Park SB, Lee SY. Depression and its influencing factors among Korean medical and engineering students in urban areas using Zung Self-Rating Depression Scale. Korean J Fam Med. 2009;30(7):539-548.

[2] Crisp, G. (2009) Conceptualization and initial validation of the College Student Mentoring Scale (CSMS). Journal of College Student Development, 5o, 177-94.

[3] Gershenfeld, S. (2014). A review of under-graduate mentoring programs, Review of Educational Research, 84, 365-91.

[4] Jacobi, M. (1991). Mentoring at-risk students in a remedial mathematics course, Mathematics and Computer Education, 106-18.

[5] O’Brien M, Llamas M, and Stevens E. (2012). Lessons learned from four years of per mentoring in a tiered group program within education, Journal of the Australia and New Zealand Student Services Association, 40, 7-15.

[6] Campbell C.M, Smith M, Dugan J.P, and Komives S.R. (2012). Mentors and college student leadership outcomes: The importance of position and process. The Review of Higher Education, 35(4), 595-625.

[7] Chester A, Burton LJ, Xenos S, and Elgar K. (2013). Peer mentoring: Supporting successful transition for first year undergraduate psychology students. Australian Journal of Psychology, 2013(65), 30-47.

[8] Thirty H, and Laursen S.L. (2011). The role of student-advisor interactions in apprenticing undergraduate researchers into a scientific community of practice. Journal of Science Education and Technology, 20, 771-84.

[9] Dolan E, and Johnson D. (2009). Toward a holistic view of holistic undergraduate research experiences: An exploratory study of impact on graduate/postdoctoral mentors. Journal of Science Education Technology, 2009(18), 487-500.

[10] Drake J.K. (2011). The role of academic advising in student retention and persistence. About Campus, 16(3), 8-12.

[11] McKimm, J., Jollie, C., \& Hatter, M. (2007). Mentoring: Theory and practice. Retrieved June19, 2013, from: 
http://www.faculty.londondeanery.ac.uk/elearning/feedback/files/Mentoring_Theory_and_Practic e.pdf.

[12] Ramani, S., Gruppen, L., \& Kachur, E. K. (2006). Twelve tips for developing effective mentors. Medical Teacher,28(5), 404-408.

[13] Murray, M., Beyond the Myths and Magic of Mentoring, Jossey-Bass, San Francisco, CA, 1991.

[14] Argente-Linares, Eva; Pérez-López, M. Carmen; Ordóñez-Solana, Celia (2016-10-19). "Practical Experience of Blended Mentoring in Higher Education". Mentoring \& Tutoring: Partnership in Learning. 24 (5): 399-414. doi:10.1080/13611267.2016.1273449. ISSN 1361-1267.

[15] Roche, G.R. (1979) Much ado about mentors, Harvard Business Review, 1, pp. 14-31.

[16] Freeman, R. (1997) Information shared in mentoring must remain confidential, British Medical Journal, 314(7074), p. 149.

[17] Gupta, S., Jindal, V., Gulati, P., Walia, D.K., \& Sarpal, S.S. (2013). Effect of mentoring on psychosocial behavior, lifestyle, sexual behavior and health condition of professional students. Jahrbuch fur Psychologie and Psychotherapie, 3(2), 112.

[18] Prince, B. (2004). Mentoring: The key to clinical learning. Nursing standard, 18, 1-2. Doi: 10.7748/ns2004.09.18.52.1.c6647.

[19] Agholor, D., Lleo, A., \& Serrano, N. (2017). Mentoring future engineers in higher education: a descriptive study using a developed conceptual framework. Production, 27(spe), e20162207. http://dx.doi.org/10.1590/0103-6513.220716.

[20] Alison, T., Steve, M., \& Sarah, C. Making mentoring work: Training for quality. Volume5. Number1. 1997. Pp.6-9. MCB University Press: ISSN 0968-4875.

[21] Eby, L.T., and Dolan, E.L. (2015). Mentoring in postsecondary education and organizational settings. In APA Handbook of Career International, Volume 2: Applications, P.J. Hartung, M.L. Savickas, and W.B. Walsh, eds., Washington, DC, USA: American Psychological Association, pp.383-95.

[22] Fox, A., Stevenson, L., Connelly, P., Duff, A., and Dunlop, A. (20100. Peer-mentoring undergraduate accounting students: The influence on approaches to learning and academic performance. Active Learning in Higher Education, 11, 145-56.

[23] Bettinger, E., and Baker, R. (2011). The effects of student coaching in college: An evaluation of a randomized experiment in student mentoring. National Bureau of Economic Research Working Paper 16881. Retrieved from: http://www.nber.org/papers/w16881 [accessed on: 15 September, 2015].

*Corresponding author.

E-mail address: attri.1@ iitj.ac.in 